DOI: $10.5613 /$ rzs.43.3.6

\section{Ivan Cifrić, Tijana Trako Poljak, Ksenija Klasnić (ur.) \\ Hrvatski identitet u promjeni? Relacijski identiteti 2}

Zagreb: Hrvatsko sociološko društvo, Institut za društvena istraživanja (IDIZ), Zavod za sociologiju Odsjeka za sociologiju Filozofskog fakulteta, 2013, 295 str.

Nakon prvog zbornika pod naslovom Relacijski identiteti: prilozi istraživanju identiteta hrvatskog društva (2008), u okviru projekta Modernizacija $i$ identitet hrvatskog društva: sociokulturne integracije i razvoj, pred nama je zbornik radova koji, kako u predgovoru navodi jedan od urednika Ivan Cifrić, čini dopunu planiranoj cjelini empirijskoga rada započetog 2004. godine.

Zbornik, uz predgovor te metodološke i konceptualne napomene urednikâ, sadržava tri dijela. Unutar prva dva dijela (»Socio-kulturni identitet $\mathrm{i}$ slika Hrvatske« i »Aspekti identiteta«) osam je autorskih radova, a treći dio, »Prilozi«, sadržava sažetke radova, bibliografiju objavljenih radova na projektu (od 2007. do 2012.), tablične prikaze rezultata anketnog istraživanja te biografije autora/autorica radova $u$ zborniku.

U predgovoru Ivan Cifrić napominje da u zborniku nisu primarno zastupljeni teorijski ili povijesni aspekti propitivanja fenomena identiteta kao takvoga, pa niti identiteta hrvatskog društva, nego konkretna empirijska provjera nekih odrednica sociokulturnog identiteta. Podsjećajući da se promjene identiteta mogu istraživati na kolektivnoj (sociokulturnoj) razini društva i na globalnoj razini, Cifrić ističe da se provedeno istraživanje odnosi na prvu razinu - sociokulturni identitet $-\mathrm{i}$ to na identitet $\mathrm{u}$ hrvatskome društvu (na percepciju sociokulturnih obilježja pojedinih društvenih skupina - etničkih, religijskih, regionalnih itd.) i na identitet hrvatskog društva u cjelini, tj. na cijelu populaciju (str. 10-11). U nastavku, Tijana Trako Poljak i Ksenija Klasnić obrazlažu koncept i metodologiju istraživanja te neke manje promjene $\mathrm{u}$ odnosu na istraživanje provedeno 2004. godine. Opisujući cilj istraživanja, kažu da je ono bilo usredotočeno na empirijsku provjeru mogućih promjena važnosti obilježja identiteta hrvatskog društva u odnosu na prethodno istraživanje.

Prvi dio zbornika, »Socio-kulturni identitet i slika Hrvatske«, sadržava tri priloga. U prvome, Ivan Cifrić pod naslovom »Dimenzije sociokulturnog identiteta (Promjene obilježja od 2004. do 2010.)« najprije obrazlaže istraživane dimenzije identiteta. $U$ istraživanju se pošlo od teze da postoji nekoliko dimenzija koje u svom međuodnosu tvore osnovne odrednice identiteta: »teritorijalna«, »socijalna«, »kulturna« i »obiteljsko-rodna" dimenzija. Usporedbom rezultata dobivenih 2004. i 2010. godine, utvrđeno je da se u tom razdoblju smanjio »osjećaj važnosti pripadanja« naciji, obiteljskoj lozi (generacijama), kraju/regiji u kojem/kojoj je 
ispitanik rođen ili živi, gradskoj četvrti u kojoj živi i pripadnosti skupini ljudi koji govore istim jezikom kao ispitanik (str. 59). U tom smislu autor izvodi zaključak da se ili smanjuje važnost nacionalne komponente ili pak povećava građanska komponenta $\mathrm{u}$ sociokulturnom identitetu. No, isto tako, napominje da ne treba zanemariti empirijske podatke koji pokazuju da više od $70 \%$ ispitanika smatra »važnim« pripadnost lozi (generacijama), kraju u kojem je rođen/a, običajima rodnoga kraja i kulturnoj tradiciji. S opaskom da se uočene promjene $\mathrm{u}$ kratkom razdoblju između dvaju istraživanja ne mogu smatrati čvrstim dokazom o promjenama identiteta hrvatskog društva u cjelini, autor zaključuje da je riječ o pokazatelju stanja subjektivne percepcije identiteta i mogućeg nastavka opisanih promjena (str. 60).

Slijede dva priloga s naslovima »Stavovi o slici Hrvatske u drugim zemljama« i »Mišljenja građana o pripadnicima različitih naroda i vjera«, čiji su autori Ksenija Klasnić i Izvor Rukavina. U prvome se prilogu usredotočuje na stavove ispitanika o percepciji, odnosno prepoznatljivosti Hrvatske u inozemstvu. Uvidi u dobivene rezultate općenito bi se mogli sažeti u zaključ$\mathrm{ku}$ da, prema mišljenju ispitanika, na sliku koju u drugim zemljama imaju o Hrvatskoj najviše utječu tri sadržaja - turizam, prirodne ljepote i hrvatski sportaši, dok slobodu medija i ideologije (komunističko nasljeđe, antifašizam i ustaštvo) procijenjuju kao sadržaje $\mathrm{s}$ najmanjim utjecajem (str. 80-81).
U drugom prilogu Klasnić i Rukavina propituju način na koji građani Hrvatske percipiraju sebe i druge. $\mathrm{Na}$ samom početku napominju da su prethodna istraživanja pokazala da oni ispitanici koji ističu važnost nacionalnovjerske dimenzije vlastitog identiteta po pravilu imaju negativno stajalište o Srbima i o pripadnicima drugih vjerskih skupina. Pokazalo se da je najviše ispitanika u izrazito pozitivnom svjetlu percipiralo pripadnike dominantne nacionalne i religijske skupine, Hrvate $\mathrm{i}$ katolike, nasuprot negativnom mišljenju o pripadnicima alternativnih religijskih skupina. O gotovo svim pripadnicima drugih naroda i vjera otprilike polovina ispitanika nema ni pozitivno ni negativno mišljenje, iako postoje određene razlike u tendencijama toga mišljenja (str. 115). Osim toga, pokazalo se da ispitanici iz Istre, Primorja i Gorskog kotara odskaču u pozitivnoj procjeni Drugih u odnosu na ispitanike iz drugih hrvatskih regija.

Drugi dio zbornika, »Aspekti identiteta«, sadržava pet priloga koji se odnose na istraživanja aspekata identiteta. Prvi je prilog Krunoslava Nikodema »Institucionalna religioznost u suvremenom hrvatskom društvu« koji, osim kraćeg pregleda za temu relevantnih teorijskih pristupa unutar sociologije religije i metodološkh napomena vezanih uz empirijsko istraživanje, donosi pokazatelje institucionalne religioznosti. Uspoređuju se rezultati istraživanja iz 2010. godine s rezultatima drugih istraživanja provedenih u posljednjih desetak i više godina. Autor zaključuje 
da u suvremenom hrvatskom društvu još uvijek prevladavaju tradicionalni oblici religioznosti vezani uz religijske institucije. Kad je riječ o pojedinim sociodemografskim obilježjima ispitanika, prvom radnom hipotezom autor je pretpostavio da će građani starije životne dobi, ženskog spola i s nižim stupnjem obrazovanja biti skloniji institucionalnim obrascima religioznosti, drugom da će tim obrascima religioznosti biti skloniji oni koji su većinu svog života proveli u ruralnim sredinama te oni iz obitelji lošijega imovinskog stanja, a trećom da će im biti skloniji građani »desne« političke orijentacije. Prva je hipoteza istraživanjem potvrđena, ali druga i treća nisu. Naposljetku, Nikodem razmatra perspektive budućih istraživanja i izdvaja pitanje o tome jesu li procesi religijske revitalizacije i retradicionalizacije s početka devedesetih godina prošlog stoljeća, uočeni u brojnim ranijim istraživanjima, završeni ili slijedi nova faza religijske retradicionalizacije uvjetovane sve lošijim socioekonomskim prilikama i prijeporima oko ulaska Hrvatske u Europsku uniju (str. 145).

Polazeći od ideje da način na koji se odnosimo prema religijskim simbolima može poslužiti kao indikator odnosa prema religijama kojima oni pripadaju, Tijana Trako Poljak istražila je odnos prema pojedinim religijskim simbolima u hrvatskome društvu te pokušala utvrditi mogu li se razlike u odnosu prema simbolima svoje i drugih religija pripisati određenim sociodemografskim obilježjima ispitanika (str. 151). U istraži- vanju su se ispitivali stavovi ispitanika prema trima tradicionalno najistaknutijim religijama u Hrvatskoj (kršćanstvu, islamu i židovstvu) preko religijskih simbola koji ih predstavljaju (križ, polumjesec i Davidova zvijezda). Rezultate autorica analizira u prilogu pod naslovom »Simboli kršćanstva, islama i židovstva u hrvatskom društvu« te zaključuje da u hrvatskome društvu postoji izrazito pozitivan stav prema križu, simbolu kršćanstva, dok su ispitanici ambivalentni, odnosno neodlučni prema simbolima islama i židovstva.

Na pitanja čijim bi interesima trebalo služiti visoko obrazovanje i koje se obrazovne ideje promiču unutar visokoga školstva u hrvatskome društvu, Nenad Karajić pokušava odgovoriti u prilogu pod naslovom »Hrvatski sustav visokog obrazovanja - između humanizacije i marketizacije znanja«. Koncepcije visokoga obrazovanja koje su prisutne u hrvatskoj javnosti autor dijeli prema njihovim sadržajnim strukturama na »humanističku ili neohumanističku koncepciju« i »tržišnu koncepciju« i pokazuje da se u Hrvatskoj izražava podrška i jednoj i drugoj koncepciji.

Uspoređujući rezultate istraživanja seksističkog diskursa, Branka Galić, pod naslovom »Seksisitički diskurs u Hrvatskoj: usporedbe i promjene, prema rezultatima istraživanja 2004. i 2010. godine« utvrđuje postojanje konzistentnih latentnih dimenzija seksističkih koncepata: androcentrizam, patrijarhalizam i rodni egalitarizam u oba istraživanja. Iako u hrvatskome društvu prevladava tradicionalni koncept seksizma, autorica 
ističe da se jasno prepoznaje i koncept rodnog egalitarizma koji odstupa od androcentričkih i patrijarhalnih koncepata, a koji podupiru mlađi i obrazovaniji dijelovi populacije, ponajprije žene. $\mathrm{Na}$ temelju dobivenih rezultata vidljivo je da se taj koncept temeljitije pozicionirao u hrvatskom društvu (str. 221-222).

$\mathrm{Na}$ kraju u posljednjem prilogu, Ivan Cifrić pod naslovom »Sociokulturni identitet $\mathrm{i}$ vrednote svjetskog ethosa« prikazuje i komentira rezultate vezane uz: (1) percepciju tvrdnji (teza) o svjetskom poretku, miru, dijalogu i svjetskom ethosu; (2) percepciju vrednota svjetskog ethosa (na temelju Deklaracije o svjetskom ethosu); (3) percepcije vrednota svjetskog ethosa u kontekstu sociokulturnog identiteta; (4) značajnost razlika sociodemografskih obilježja (a) u percepciji poretka, mira i dijaloga - »novi svjetski poredak« i (b) u percepciji poštovanja vrednota svjetskog ethosa (str. 230). Istraživanje percepcije teza o »novome svjetskom poretku « pokazalo je da se između $73,2 \%$ i $84,5 \%$ ispitanika slaže s postavljenim tvrdnjama o uvjetima nastanka praved- nijega svjetskog poretka, o svjetskom miru, religijskom miru i dijalogu. Nasuprot širokoj prihvaćenosti vrednota, procijenjeno je da su one slabo prisutne u hrvatskome društvu jer između 35,7\% i $56,9 \%$ ispitanika smatra da se vrednote svjetskoga ethosa u njemu ne poštuju (str. 247).

Naposljetku treba istaknuti da posebna vrijednost ovog zbornika proizlazi iz činjenice da su radovi koji su u njemu objavljeni nastali na temelju višedimenzionalno koncipiranog istraživanja sociokulturnih identiteta $\mathrm{u} \mathrm{hr}$ vatskom društvu koje, zahvaljujući teorijskoj i metodološkoj konzistentnosti, omogućuje usporedbu prikupljenih podataka i dobivenih rezultata $u$ vremenskom razmaku od šest godina. Osim toga, budući da je znanstvenoistraživački rad na projektu čiji se rezultati donose bio usmjeren i na razvijanje metodologije na području istraživanja identiteta, to je još jedan vrijedan doprinos ovoga zbornika.

Ivanka Buzov Odsjek za sociologiju Filozofskog fakulteta Sveučilišsta u Splitu 